\title{
手作業を目的とした人間型ロボットの全身動作生成
}

\author{
井上 健 司*1 西 濱 祐 介*2 坂 田 幸太郎*3 \\ 新 井 健 生*1 前 泰 志*4
}

\section{Generating Whole Body Motion of Humanoid Robots for Manipulation Tasks}

\author{
Kenji Inoue $^{* 1}$, Yusuke Nishihama*2, Kotaro Sakata*3, \\ Tatsuo Arai*1 and Yasushi Mae ${ }^{* 4}$
}

\begin{abstract}
A control method for humanoid robots of mobile manipulation is proposed. A robot autonomously generates its whole body motion and steps so as to increase arm manipulability and robot stability, while performing various manipulation tasks with its hands; that enables dexterous and stable manipulation. An objective manipulation task is given as the desired trajectories of both hands, and external forces may be applied to the hands. For carrying out this task, the hands are always controlled along their desired trajectories by impedance control. Coordinating with this motion of the hands, the robot controls its body and legs so that the hands may be easy to perform the task. It determines the next foothold by evaluating manipulabilities of both arms, direction of stable region and moving direction. An evaluation function consisting of manipulabilities of both arms and static stability of the robot is defined, and the robot steps if the new double support state is better than the current one. Both in double and single support states, the robot controls its body pose using the support leg/legs so that this evaluation function may be optimal. The swing leg is moved to the next foothold in single support state. Various motions of humanoid robot "HRP-1" by the proposed method are simulated using dynamic simulator "OpenHRP".
\end{abstract}

Key Words: Humanoid Robot, Mobile Manipulation, Manipulability, Stability

\section{1.はじめに}

近年になり，人間型ロボットのハードウェア面での実現可能性が 示されたことで，その実用化に向けたハードウェアのさらなる高 度化・システム化 [1]〜 [6], 動作制御 [7] [8], 移動経路生成 [9] [10], 全身動作生成 [11]～[14], 転倒や起き上がり動作 [15]～[17], 遠 隔操作 [18]～[20], ソフトウェアやシミュレーション技術 [21] [24] などに関する研究が数多くなされている，ところで，人間 型ロボットは単に歩行するだけでなく, 両手で作業を行うこと ができるのも大きな特徵である，対地適応性に優れ，接地面積 や移動に要する空間が小さくてすむという利点を持った人間型 ロボットは, 人が生活する空間を移動したり, 人と協調作業を 行ったりするのに有効といえる.こうした理由から, 近い将来,

原稿受付 2004 年 8 月 13 日

${ }^{* 1}$ 大阪大学大学院基礎工学研究科

*2 日本電気株式会社

$* 3$ 松下電器産業株式会社

*4 福井大学丁学部

${ }^{* 1}$ Graduate School of Engineering Science, Osaka University

${ }^{* 2}$ NEC Corporation

${ }^{* 3}$ Matsushita Electric Industrial Co., Ltd.

${ }^{* 4}$ Faculty of Engineering, University of Fukui
人間型ロボットは，オフィスや家庭といった環境で様々な作業 を行い, 人々の日常生活を支援することが期待されている. 井 上 [25] や比留川 [26] は，人間支援を含めた人間型ロボットの将 来の応用分野について展望している。我々も，インターネット によるアンケート調査により，身の回りで働くロボットとして の人間型ロボットに対する人々の期待が大きいこと, 特にホー ムサービスやセキュリティといった分野への応用が求められて いることを確認している [27]. しかし, 作業を行うロボットと いう視点から人間型ロボットの汎用的な動作生成を行う研究は 少ない. HRP プロジェクト [28] [29]では, 具体的作業を取り上 げて人間型ロボットの適用可能性を示している。最近では, 重 量物を押すなどの力作業に人間型ロボットを適用する研究が行 われている [30]〜 [32].

人間型ロボットへの応用が期待されている作業には, 人がそ うであるように本質的に手を使って行うものが多いと考えられ る. 人間型ロボットが手作業を行う場合には, 腕と脚を切り離 して制御するのではなく, 作業を行う腕の動作と協調させて胴 体・脚を動かすことで, 腕の手作業の能力を補完・増強するこ とができる。我々は，このような手作業を目的とする全身動作 を「作業移動」と呼び, 人間型ロボットに作業移動を実現させ る研究を行っている [33]〜 [38]. 
文献 [34] では, sagittal plane 内の運動に限定し, 歩幅を固 定した場合の作業移動の一手法を提案した。本研究ではこれを 発展させ，二次元平面上での踏みかえを行う人間型ロボットの 作業移動制御法を提案する。この方法は, 単なる歩行とは異な り，手作業を目的とする全身制御法である。すなわち，「手で 様々な作業を遂行しながら，それに合わせてその場での胴体姿 勢制御や踏みかえを自律的に切り替えることで, 腕の手作業の 能力やロボットの安定性を高め, 器用かつ安定な手作業を可能 にする」人間型ロボットの全身動作を生成する。そして，仮想 プラットフォーム OpenHRP [21]～[23] を用いて提案した作業 移動制御法による人間型ロボット HRP-1の様々な動作のシミュ レーションを行い, その有効性を検証する.

\section{2. 人間型ロボットの作業移動}

Fig. 1 は，人間型ロボットで想定される作業例を示したもの である. Fig. 1 (a) は人との協調による物体運搬・組み付け作業 で，人が物体を押したり引いたりすることで, 人間型ロボット の手に運搬方向等の指示が直接与えられる.人間型ロボットは, 手を指示通りに動かしながら，手の動きに合わせて腕や体全体 を上下動させる，前後左右に移動する，その場で旋回するといっ た脚動作を行わなければならない. Fig. 1(b) は掃除などに見ら れる動作で, 手で機器を動かすのが目的なので作業の主体は手 であり，手の動きに合わせた移動が求められる．加えて，機器 を介して手に作用する外力（外乱）に対しても対応できる必要
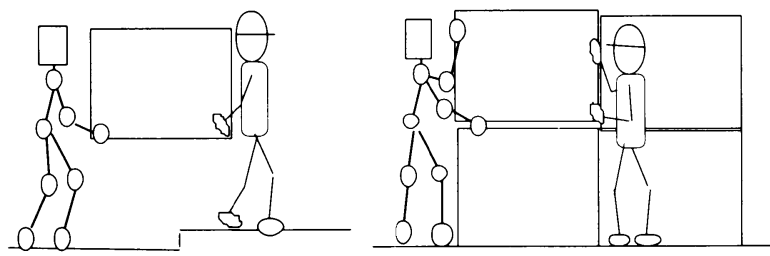

(a) Carrying and fixing panel with human worker

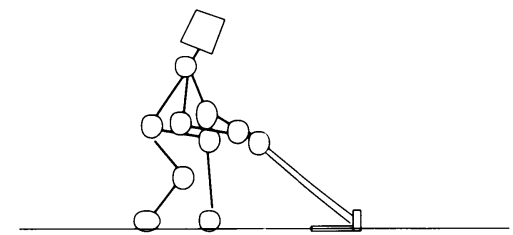

(b) Sweeping floor

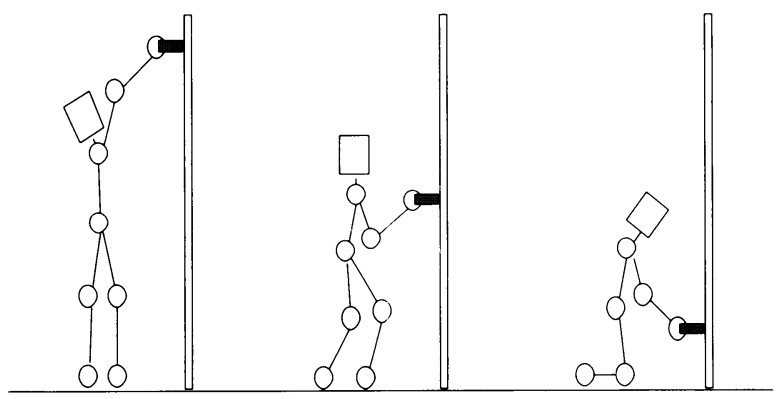

(c) Object manipulation on different levels

Fig. 1 Examples of tasks which humanoid robots are expected to do
がある. Fig. 1 (c) のように高さの異なる場所で手作業する場合 には，大きな移動は伴わないものの，背伸びしたりひざまずい たりして，手が作業しやすいように姿勢を調整したり，立つ位 置を変更することが重要となる.

以上の例に限らず，人間型ロボットが行う作業には，手を使っ たものが多いと考えられる。その際，作業を行う腕の動作と協 調させて，上で述べたような胴体の高さや姿勢の変更，移動・ 旋回・立ち位置の調整といった胴体・脚動作を行うことで, 腕 の手作業の能力を補完・増強することができる．本論文では, このような手作業を目的とする全身動作を「作業移動（Mobile Manipulation)」と呼ぶ.

\section{3. 人間型ロボットのモデル}

本研究では, 胴体に 2 本の腕と 2 本の脚がついた構造の人間 型ロボットを対象とする, 胴体に自由度はなく, 脚は, 胴体に対 して足の位置·姿勢を制御できる 6 自由度を持つとする．腕は, 作業に必要な自由度 $m$ を持つ. 空間の位置だけなら $m=3$, 位 置と姿勢が必要なら $m=6$ となる.

Fig. 2 に，人間型ロボットの関節構成の一例 $(m=6)$ を示 す. 左右の腕の関節変数を $\boldsymbol{q}_{a l}, \boldsymbol{q}_{a r} \in R^{m}$, 左右の脚の関節変 数を $\boldsymbol{q}_{l l}, \boldsymbol{q}_{l r} \in R^{6}$ とする. また, 地面に固定された座標系か ら見た左右の手の位置・姿勢を $\boldsymbol{r}_{h l}, \boldsymbol{r}_{h r} \in R^{m}$, 左右の足の位 置・姿勢を $\boldsymbol{r}_{f l}, \boldsymbol{r}_{f r} \in R^{6}$, 肩 (Fig. 2 の点 $\mathrm{S}$ ) の位置·姿勢 を $\boldsymbol{r}_{s} \in R^{6}$ とする.このとき, 腕・脚の逆運動学は, 次のよう な形に表すことができる.

$$
\begin{aligned}
\boldsymbol{q}_{a i}=\boldsymbol{g}_{a i}\left(\boldsymbol{r}_{s}, \boldsymbol{r}_{h i}\right) & (i=l, r) \\
\boldsymbol{q}_{l i}=\boldsymbol{g}_{l i}\left(\boldsymbol{r}_{s}, \boldsymbol{r}_{f i}\right) & (i=l, r)
\end{aligned}
$$

上式より, 両手, 両足, 肩の位置·姿勢を計画できれば, ロボッ トの全関節の目標角が計算できる。これを各関節の位置フィー ドバック・コントローラに入力してロボットを動かす。そこで, 次章では両手, 両足, 肩の位置・姿勢の生成法を提案する.

本研究では, 手作業する際に対象物から手に力・モーメント が作用する状況も考えるため, 左右の手に作用する力・モーメ ントを $\boldsymbol{f}_{h l}, \boldsymbol{f}_{h r} \in R^{m}$ と表す.

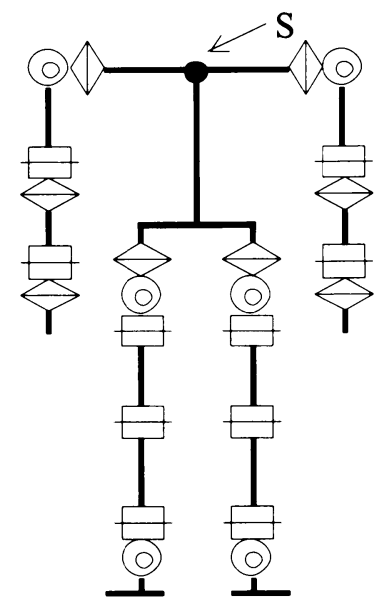

Fig. 2 Example of humanoid robot model 


\section{4. 作業移動制御法}

\section{1 作業移動制御法の概要}

作業移動制御法の概要を Fig. 3 に示す.

手作業を目的とする作業移動では，作業によって決まる手の 目標位置・姿勢や目標軌道が与えられる。また，対象物から手 に力・モーメントが作用する状況では，作業によって決まる手 の目標力・モーメントも与えられることになる．作業を遂行す るためには，この与えられた目標運動に従って手を動かすこと が, 第一の目標となる。本研究では, 未来の目標運動があらか じめ分かっているのではなく, 実時間で与えられる目標運動に 応じて全身動作を生成することを考える。

手を目標運動に従って動かすという制約条件のもとで, 胴体 の位置・姿勢やロボットの立つ位置は，圥長自由度である。この 冗長自由度を用いることで，腕の手作業の能力を高めることが できる，まず，手作業を遂行するためには，手で器用に作業でき ること, 手に働く外力の変化にも腕が即座に対応できることが 求められる.また，細かい手作業は踏みかえずに腕を使って実現 することが望ましい. そこで，作業を行う手の位置·姿勢に対し， 両腕の操作性を高い状態に保つように肩の位置・姿勢を移動させ

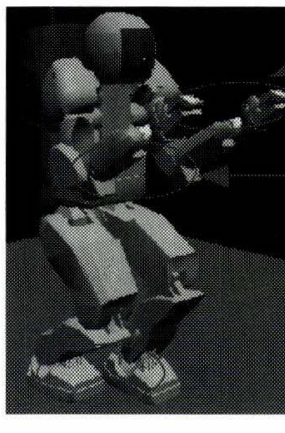

\section{(1) Hand motion for performing task} Increasing arm manipulability 凤

Body and leg motion

Keeping robot stability

(a) Basic idea of mobile manipulation

(2) Foothold determination

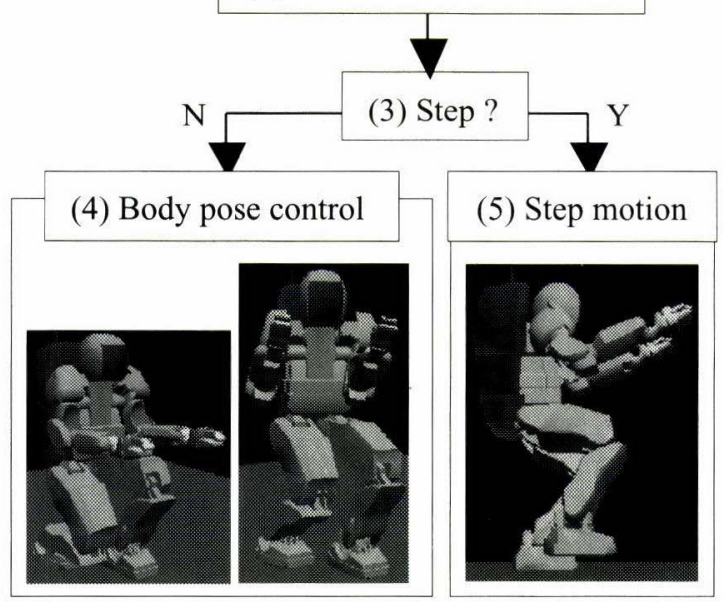

(b) Body and leg control for optimizing arm manipulability and robot stability

Fig. 3 Outline of mobile manipulation control for humanoid robot
る。そして, 手の細かい運動や突然の外力の変化には腕だけが 応答するようにすれば，効率よい手作業が可能となる，言い換 えれば，腕の動作領域が手の周囲に広がるように肩の位置·姿勢

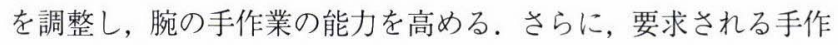
業の範囲が広い場合は踏みかえて, 腕の動作領域を移動させる (Fig. 4 (a)). 器用さと同時に, 安定した手作業を維持するため には，ロボットが転倒しないことも重要である。よって, ZMP を安定領域内に保つことが求められる (Fig. 4 (b)). 以上のこ とから, 作業を遂行する両手の運動に対し, これら二つの評価 指標（両腕操作性とロボット安定性）を高めるように胴体・脚を 制御すれば，器用かつ安定な手作業が実現できる（Fig. 3 (a)).

よって, 作業移動制御法の基本的な考え方は, 「作業によって 決まる目標運動に両手を追従させながら，それにあわせて作業 を行う両腕の操作性およびロボット全体の安定性を高く維持す るように胴体・脚を制御する」ことである。車輪式移動ロボッ トと違い, 人間型ロボットを含めた脚式移動ロボットでは, 移 動のために踏みかえる必要がある。したがって, 胴体・脚の制 御は, Fig. 3 (b) のように着地点候補の決定, 踏みかえの判断, 両脚支持状態での胴体姿勢制御, 踏みかえ動作の制御からなり, ロボットは自律的に判断して両脚支持状態と踏みかえ動作を切 り替える。なお, 本研究では, 高さが既知の地面に着地する場 合を扱う。

作業移動制御法の手順を以下にまとめる。(1)～(5) は, Fig. 3 中の番号に対応している.

（1）作業によって決まる目標運動に常に追従させるように，両 手を制御する.

（2）踏みかえ後の安定領域の方向と両腕操作性, および進行方 向を考慮して，着地点候補を決定する。
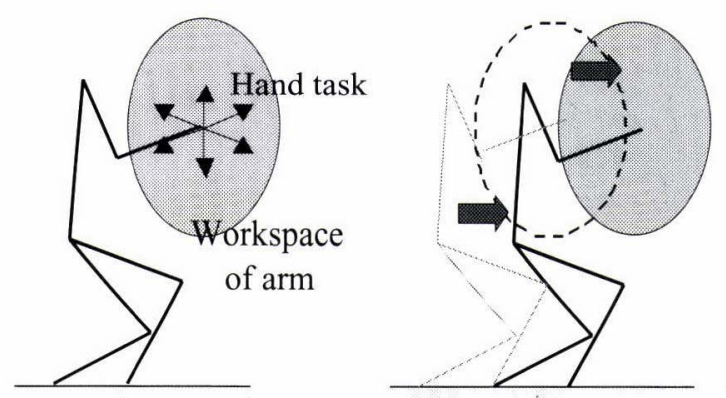

(a) For dexterous manipulation

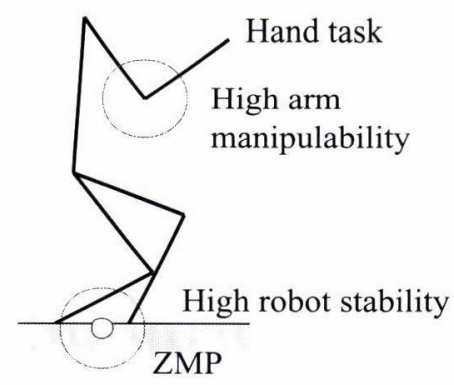

(b) For dexterous and stable manipulation

Fig. 4 Optimal pose of humanoid robot for mobile manipulation 
（3）両腕操作性とロボット安定性を評価する作業移動評価関数 を定義し, 現在の両脚支持状態よりも踏みかえ後の両脚支 持状態の評価值がよければ，踏みかえると判断する.

（4）踏みかえない場合は，現在の両脚支持状態で作業移動評価 関数を最適にするように肩の位置・姿勢を制御する。

（5）踏みかえる場合は，遊脚を着地点に向かって移動させなが ら，支持脚を使って作業移動評価関数を最適にするように 肩の位置・姿勢を制御する。

作業を遂行するため，胴体・脚の状態によらず（1）は常に行う. 両脚支持中は $(2)$ （4）を繰り返し行って着地点候補を逐次更 新し，踏みかえるかどうかを判断する。踏みかえを開始したら (2)，（3）は行わず，求めた着地点に踏みかえて新しい両脚支持 状態に移る。

以上の方法により，器用かつ安定な手作業を実現する。

\section{2 両手のインピーダンス制御}

両手には，作業によって決まる目標位置・姿勢 $\boldsymbol{r}_{h i d}(i=l, r)$ と目標外力・モーメント $\boldsymbol{f}_{h i d}(i=l, r)$ が与えられる。作業を 遂行するためには，この目標運動に従って両手を動かす必要が ある.そこで，インピーダンス制御により常に両手を制御する。

$$
\begin{aligned}
& M_{h i} \ddot{\boldsymbol{r}}_{h i}+D_{h i}\left(\dot{\boldsymbol{r}}_{h i}-\dot{\boldsymbol{r}}_{h i d}\right)+K_{h i}\left(\boldsymbol{r}_{h i}-\boldsymbol{r}_{h i d}\right) \\
& =\boldsymbol{f}_{h i}-\boldsymbol{f}_{h i d} \quad(i=l, r)
\end{aligned}
$$

ここで， $M_{h i}, D_{h i}, K_{h i}$ は, 両手の理想インピーダンスであ る. 式（3）より導かれる次式により両手の理想加速度を求め, サンプリング時間 $\Delta t$ だけ積分して両手の位置・姿勢の指令值 を生成する。

$$
\begin{gathered}
\ddot{\boldsymbol{r}}_{h i}(t)=M_{h i}^{-1}\left\{\boldsymbol{f}_{h i}(t)-\boldsymbol{f}_{h i d}(t)-D_{h i}\left(\dot{\boldsymbol{r}}_{h i}(t)-\dot{\boldsymbol{r}}_{h i d}(t)\right)\right. \\
\left.-K_{h i}\left(\boldsymbol{r}_{h i}(t)-\boldsymbol{r}_{h i d}(t)\right)\right\} \quad(i=l, r) \\
\boldsymbol{r}_{h i}(t+\Delta t)=\boldsymbol{r}_{h i}(t)+\dot{\boldsymbol{r}}_{h i}(t) \Delta t+\frac{1}{2} \ddot{\boldsymbol{r}}_{h i}(t) \Delta t^{2} \\
(i=l, r)
\end{gathered}
$$

\section{3 着地点候補の決定}

着地点候補は，踏みかえ後の安定領域の方向と両腕操作性，お よび進行方向を考慮した評価関数 $V$ を用いて決定する．以下， 左足を踏みかえる場合で説明する. Fig. 5 の $\boldsymbol{r}_{f i}(i=l, r)$ は現 在の両足接地点, $\hat{\boldsymbol{r}}_{f l}$ は決定すべき踏みかえ後の左足着地点を 表す.

多脚ロボットとは異なる大きな特徴として，2 足で立つ人間型 ロボットは両脚支持状態における安定領域が細長い。したがっ て，あらゆる方向に同等な安定領域を確保することはできない ので，安定に手作業を遂行するためには，着地後の安定領域の 長手方向が ZMP の変動しやすい方向になるように着地点を決 定する必要がある。つまり，支持脚である右足の接地点 $\boldsymbol{r}_{f r}$ を 通り ZMP の変動しやすい方向を向く地面上の直線（Fig. $5(\mathrm{a})$ の $\left.\mathrm{L}_{1}\right)$ 上に左足を着地することが望ましい. そこで，安定領域 の方向に関する評価関数を次のように定義する.

$$
V_{1}=d_{1}^{2}
$$

$d_{1}$ は $\mathrm{L}_{1}$ と左足着地点 $\hat{\boldsymbol{r}}_{f l}$ との距離で, $V_{1}$ が小さいほど $\mathrm{L}_{1}$ 近

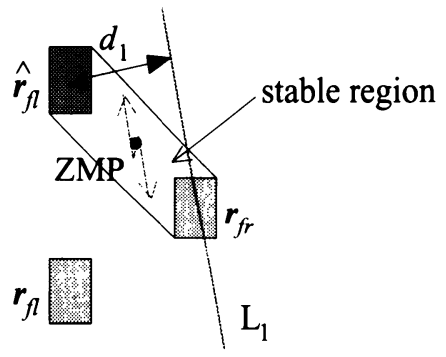

(a) Evaluation of stable region after step

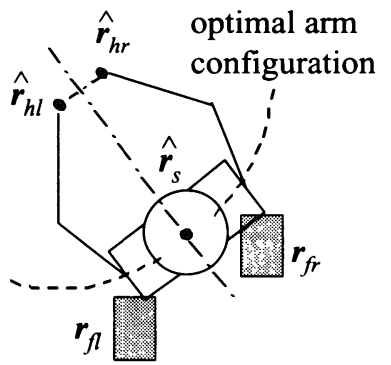

(b) Predicted shoulder pose after step

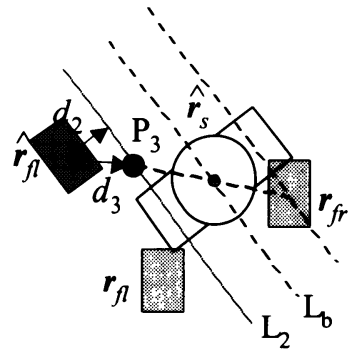

(c) Evaluation of arm manipulability after step and moving direction

Fig. 5 Next foothold determination

くに左足を着地することを意味する．ZMP の変動しやすい方 向としては，両手の移動方向または両手に作用する外力の方向 にとる。

両手で作業することを考えると，作業によって決まる踏みか え後の両手の位置・姿勢に対し, 着地後の両腕の可操作度が高 く，両手が胴体正面にあることが望ましい，ただし，本研究で は未来の両手目標軌道はあらかじめ与えられていないとしてい る.そこで，あらかじめ設定された踏みかえ時間 $t_{s}$ と現在の両 手の位置 ·姿勢 $\boldsymbol{r}_{h i}(i=l, r)$ およびその速度 $\dot{\boldsymbol{r}}_{h i}$ から, 現在の 速度で等速運動を続けると想定して踏みかえ後の両手の予測位 置・姿勢 $\hat{\boldsymbol{r}}_{h i}$ を求める.

$$
\hat{\boldsymbol{r}}_{h i}=\boldsymbol{r}_{h i}+\dot{\boldsymbol{r}}_{h i} t_{s} \quad(i=l, r)
$$

この $\hat{\boldsymbol{r}}_{h i}$ に対して，両腕操作性を最大にする肩の予測位置・姿 勢 $\hat{\boldsymbol{r}}_{s}$ を求める. 例えば手の位置だけを考えた場合, 左右の腕の 可操作度をそれぞれ最大にする腕の付け根の位置は, Fig. 5 (b) のような破線上にある（この曲線は，腕の関節構成によって異 なる)，さらに，両手を胴体正面にすることを考慮すると，両手 の中点を通り，両手を結ぶ線分に垂直で地面に水平な直線（図 の一点鎖線）上に肩があればよい。よって， $\hat{\boldsymbol{r}}_{s}$ は図のように求 
められる，左足は，踏みかえ後の胴体正面から見て $\hat{\boldsymbol{r}}_{s}$ が両脚 の中央になるように着地する。すなわち, Fig. 5 (c) のように, $\hat{\boldsymbol{r}}_{s}$ を通り胴体に垂直な直線を地面に投影した直線 $\mathrm{L}_{b}$ と右足接 地点 $\boldsymbol{r}_{f r}$ との距離を求め, $\mathrm{L}_{b}$ に平行で右足とは反対側に同距離 だけ離れた地面上の直線を $\mathrm{L}_{2}$ とすると， $\mathrm{L}_{2}$ 上に左足を着地さ せればよい，そこで，両腕操作性に関する評価関数を次のよう に定義する。

$$
V_{2}=d_{2}^{2}
$$

ここで, $d_{2}$ は直線 $\mathrm{L}_{2}$ と左足着地点 $\hat{\boldsymbol{r}}_{f l}$ との距離である.

さらに, 進行方向に踏み出すためには, 踏みかえ後の肩の予測 位置・姿勢 $\hat{\boldsymbol{r}}_{s}$ に対して右足接地点 $\boldsymbol{r}_{f r}$ と点対称の点 (Fig. 5 (c) の点 $\mathrm{P}_{3}$ ）に左足を着地するのがよい，そこで, 進行方向に関す る評価関数を次のように定義する。

$$
V_{3}=d_{3}^{2}
$$

ここで, $d_{3}$ は点 $\mathrm{P}_{3}$ と左足着地点 $\hat{\boldsymbol{r}}_{f l}$ との距離である.

着地点評価関数 $V$ は, これらの重み付き和で定義する.

$$
V=w_{1} V_{1}+w_{2} V_{2}+w_{3} V_{3} \rightarrow \min .
$$

ここで, $w_{1}, w_{2}, w_{3}(>0)$ は各評価值の重みである. ロボット の機構上の制約などによって決まる着地可能領域内で, $V$ を最 小にする着地点を左足の最適着地点とする，足首の向きは，胴 体正面方向にそろえる (Fig. 5 (c) 参照).

右足，左足を踏みかえる場合それぞれについて，最適着地点 とそのときの評価值 $V$ を計算し, 両者を比較して評価值が小さ いほうを遊脚およびその着地点候補とする，以下では，左足が 遊脚に決定したとし，その着地点候補を $\hat{\boldsymbol{r}}_{f l}$ とする.

\section{4 作業移動評価関数}

4.1 節で述べたように, 手作業中心の作業移動では両腕を操 作性の高い状態に保つことが求められる。 そこで, 両手の位置・ 姿勢 $\boldsymbol{r}_{h i}(i=l, r)$ に対し, 4.3 節の $\hat{\boldsymbol{r}}_{s}$ と同様にして両腕操作性 を最大にする肩の理想位置・姿勢 $\boldsymbol{r}_{s d}$ を求め, 局の位置・姿勢 $\boldsymbol{r}_{s}$ と $\boldsymbol{r}_{s d}$ との偏差で両腕操作性の評価值 $U_{a}$ を定義する.

$$
\begin{aligned}
\boldsymbol{r}_{s d} & =\boldsymbol{r}_{s d}\left(\boldsymbol{r}_{h l}, \boldsymbol{r}_{h r}\right) \\
U_{a} & \equiv\left(\boldsymbol{r}_{s}-\boldsymbol{r}_{s d}\right)^{T} \frac{K_{a}}{2}\left(\boldsymbol{r}_{s}-\boldsymbol{r}_{s d}\right)
\end{aligned}
$$

$K_{a}(>0)$ は評価関数の重み行列で, $U_{a}$ が小さいほど両腕操作 性が高いことを意味する.

次に，ロボットを安定した状態に保つことも重要なので，口 ボット安定性の評価値 $U_{z}$ を次式で定義する。

$$
\begin{aligned}
\boldsymbol{r}_{z} & =\boldsymbol{r}_{z}\left(\boldsymbol{r}_{h l}, \boldsymbol{r}_{h r}, \boldsymbol{r}_{s}, \boldsymbol{r}_{f l}, \boldsymbol{r}_{f r}, \boldsymbol{f}_{h l}, \boldsymbol{f}_{h r}\right) \\
U_{z} & \equiv\left(\boldsymbol{r}_{z}-\boldsymbol{r}_{z d}\right)^{T} \frac{K_{z}}{2}\left(\boldsymbol{r}_{z}-\boldsymbol{r}_{z d}\right)
\end{aligned}
$$

ここで, $\boldsymbol{r}_{z}$ は慣性力を無視した ZMP (静的 ZMP と呼ぶ), $\boldsymbol{r}_{z d}$ は目標 ZMP で, 両脚支持状態では安定領域中央に設定する. 静 的 ZMP は, 両手, 両足, 肩の位置・姿勢の関数であるロボッ ト全身の姿勢と両手に作用する外力・モーメントによって決ま る.この外力・モーメントを考慮している点で地面への重心投
影点とは異なる，本研究で考える作業移動は, 両脚支持状態で の作業を基本とし, 両脚で立つ位置を切り替えていくという考 え方である. 後述のように, 両脚支持状態では手の速い動きに 対しては質量の小さい腕で対応し, 胴体・脚はゆっくり動かす. したがって, 運動による慣性力の影響は小さいため, 静的 ZMP を用いた， $K_{z}(>0)$ は評価関数の重み行列である. $U_{z}$ が小さ いほど $\boldsymbol{r}_{z}$ が $\boldsymbol{r}_{z d}$ に近づき, ロボットは安定となる.

作業移動評価関数 $U$ は, これらの和で定義する.

$$
U\left(\boldsymbol{r}_{h l}, \boldsymbol{r}_{h r}, \boldsymbol{r}_{s}, \boldsymbol{r}_{f l}, \boldsymbol{r}_{f r}, \boldsymbol{f}_{h l}, \boldsymbol{f}_{h r}\right) \equiv U_{a}+U_{z}
$$

$U$ は両手, 両足, 肩の位置・姿勢と両手に作用する外力・モ一 メントの関数である.

\section{5 踏みかえの判断}

着地点候補 $\boldsymbol{r}_{f l}$ に踏みかえるかどうかは, 作業移動評価関数 $U$ を用いて判断する.

まず，踏みかえにはあらかじめ設定した踏みかえ時間 $t_{s}$ を要 する. 両手が現在の速度を保つと仮定して, 現在の両手の位置. 姿勢 $\boldsymbol{r}_{h i}$ から $t_{s}$ の半分の時間だけ未来の両手の予測位置·姿勢 $\tilde{\boldsymbol{r}}_{h i}$ を求める. また, 両手には現在の外力・モーメント $\boldsymbol{f}_{h i}$ が 作用しつづけるとして, 予測外力・モーメント $\tilde{\boldsymbol{f}}_{h i}$ を求める.

$$
\tilde{\boldsymbol{r}}_{h i}=\boldsymbol{r}_{h i}+\dot{\boldsymbol{r}}_{h i} t_{s} / 2, \quad \tilde{\boldsymbol{f}}_{h i}=\boldsymbol{f}_{h i} \quad(i=l, r)
$$

$\tilde{\boldsymbol{r}}_{h i}, \tilde{\boldsymbol{f}}_{h i}$ に対し, 現在の両脚支持状態（両足の位置·姿勢 $\left.\boldsymbol{r}_{f l}, \boldsymbol{r}_{f r}\right)$ において肩を最適位置・姿勢にしたときの $U$ の最小 值 $U_{m 1}$, 踏みかえたと仮定したときの両脚支持状態 $\left(\hat{\boldsymbol{r}}_{f l}, \boldsymbol{r}_{f r}\right)$ での $U$ の最小値 $U_{m 2}$ を計算する.

$$
\begin{aligned}
U_{m 1} & =\min _{\boldsymbol{r}_{s}} U\left(\tilde{\boldsymbol{r}}_{h l}, \tilde{\boldsymbol{r}}_{h r}, \boldsymbol{r}_{s}, \boldsymbol{r}_{f l}, \boldsymbol{r}_{f r}, \tilde{\boldsymbol{f}}_{h l}, \tilde{\boldsymbol{f}}_{h r}\right) \\
U_{m 2} & =\min _{\boldsymbol{r}_{s}} U\left(\tilde{\boldsymbol{r}}_{h l}, \tilde{\boldsymbol{r}}_{h r}, \boldsymbol{r}_{s}, \hat{\boldsymbol{r}}_{f l}, \boldsymbol{r}_{f r}, \tilde{\boldsymbol{f}}_{h l}, \tilde{\boldsymbol{f}}_{h r}\right)
\end{aligned}
$$

現在より踏みかえ後の評価がよいと判断したら，ロボットは 踏みかえを開始して新しい両脚支持状態に移ればよい，すなわ ち，踏みかえ開始条件は次式となる。

$$
U_{m 1}>U_{m 2}
$$

\section{6 両脚支持状態の制御}

踏みかえないと判断した場合は, 現在の両脚支持状態を維持 する. よって, 両足の位置·姿勢 $\boldsymbol{r}_{f i}(i=l, r)$ は定数となるの で, 作業移動評価関数 $U$ を最小にするように肩の位置·姿勢 $\boldsymbol{r}_{s}$ を制御する。具体的には，ロボットが最も安定となる安定領域 中央に目標 $\mathrm{ZMPr} \boldsymbol{r}_{z d}$ を設定し, 両手の位置・姿勢 $\boldsymbol{r}_{h i}(i=l, r)$ と外力・モーメント $\boldsymbol{f}_{h i}(i=l, r)$ に応じて $\boldsymbol{r}_{s}$ を次式でインピー ダンス制御する。

$$
M_{s} \ddot{\boldsymbol{r}}_{s}+D_{s} \dot{\boldsymbol{r}}_{s}=-\frac{\partial U}{\partial \boldsymbol{r}_{s}}
$$

ここで, $M_{s}, D_{s}$ は肩の理想インピーダンスである. 右辺は $U$ をポテンシャルエネルギーとみなしたときの仮想的な力に相当 し，上式により $\boldsymbol{r}_{s}$ は $\partial U / \partial \boldsymbol{r}_{s}=0$ の点に向かって制御される. 式（20）より導かれる次式により肩の理想加速度を求め, サン プリング時間 $\Delta t$ だけ積分して肩の位置・姿勢の指令值を生成 
幸太郎 新 井健 生前泰志

する。

$$
\begin{aligned}
& \ddot{\boldsymbol{r}}_{s}(t)=M_{s}^{-1}\left\{-\frac{\partial U}{\partial \boldsymbol{r}_{s}}(t)-D_{s} \dot{\boldsymbol{r}}_{s}(t)\right\} \\
& \boldsymbol{r}_{s}(t+\Delta t)=\boldsymbol{r}_{s}(t)+\dot{\boldsymbol{r}}_{s}(t) \Delta t+\frac{1}{2} \ddot{\boldsymbol{r}}_{s}(t) \Delta t^{2}
\end{aligned}
$$

式（3）で設定された両手の理想インピーダンスの応答性に 比べて肩の理想インピーダンスの応答性を低く設定することで, 両手の速い動きには腕だけが動作し，ゆっくりした動きには肩 から動かして対応させることが可能となる。

\section{7 踏みかえ制御}

作業移動における踏みかえは，移動を目的とする連続的な歩 行とは異なる。本研究で考える作業移動は, 両脚支持状態での 手作業を基本とし, 手作業がしやすい場所に画脚で立つ位置を 一歩ずつ切り替えていくという考え方である。したがって，動 歩行のように連続かつ高速に脚を動かすよりも，一歩一歩確実 な踏みかえが重要となる，そこで，以下のように作業移動評価 関数 $U$ を用いた静歩行による踏みかえを行う.

まず，Fig. 6 のように踏みかえは三つのフェーズからなる. 各フェーズ $k$ の時間 $t_{k}(k=1,2,3)$ と総踏みかえ時間 $t_{s}=$ $t_{1}+t_{2}+t_{3}$ は，あらかじめ設定する.

肩の制御：フェーズ 1 で，目標 $\mathrm{ZMP} \boldsymbol{r}_{z d}$ を現在の両脚支持状 態の安定領域中央から支持脚の足底中央に移動させる。フェー ズ 2 は単脚支持期で, $\boldsymbol{r}_{z d}$ を支持脚の足底中央に保つ. 着地後の フェーズ 3 で， $\boldsymbol{r}_{z d}$ を新しい両脚支持状態の安定領域中央に移 動させる。この間，両脚支持状態と同じ式 (20) で肩の位置·姿 勢 $\boldsymbol{r}_{s}$ を制御すると, ロボット安定性の評価值 $U_{z}$ の効果で $\boldsymbol{r}_{z d}$ に応じて $\boldsymbol{r}_{s}$ が動き, 踏みかえに必要な体重移動が実現される.

遊脚の制御：単脚支持期（フェーズ 2) の遊脚足先 $\boldsymbol{r}_{f l}$ は, 楕 円軌道に沿って着地点 $\hat{\boldsymbol{r}}_{f l}$ まで移動させる，足底で地面を蹴る 動作は行わない.

\section{8 作業移動制御法の特徵}

以上の方法により，両手で目的作業を遂行しながら，その動 きに応じて両腕操作性・ロボット安定性を高めるように胴体・脚 を制御することが可能となる。胴体・脚制御は両脚支持状態で の胴体姿勢制御と踏みかえ動作からなり，それらを自律的に切 り替えることで, 器用かつ安定な手作業を可能にする。両手が 大きく移動すると，それに合わせて連続踏みかえが起こる。こ れは, 通常の歩行とは異なり，手作業がしやすい場所に両脚で

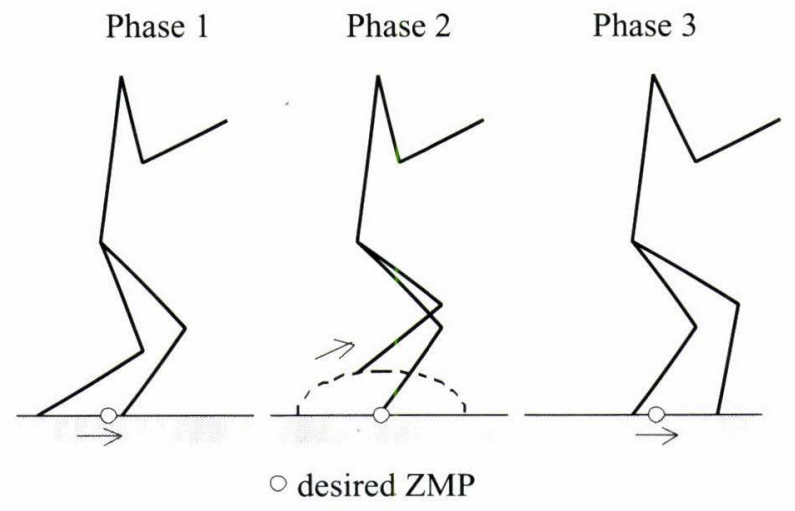

Fig. 63 phases in step motion
立つ位置を一歩ずつ切り替えていく，手作業を主体とする作業 移動といえる。

着地点候補の決定や踏みかえの判断では, 踏みかえ中, 両手 は現在の速度で等速運動を続けると想定している。よって, 手 の運動が予測した軌道と異なると, 求めた着地点は最適点から 外れてしまう。しかし, 踏みかえの途中で着地点を変更して遊 脚の動きを変えることは, 安定性の面から困難である。そこで, 提案手法では, いったん着地し, 着地後の両脚支持状態であら ためて着地点候補を求め, 必要ならば踏みかえ直すという戦略 をとる(4.1 節参照).

提案手法では作業によって決まる目標運動を両手に与えるた けで，それに応じた腕・胴体・脚の全身運動が自律的に生成さ れる。この運動はオフラインで生成しておくものではなく，現 在の両手の運動に応じて実時間で作り出されるものである.

\section{5. 人間型ロボットの作業移動シミュレーション}

\section{1 シミュレーションの設定}

提案する作業移動制御法の有効性を検証するため, 動力学シ ミュレータとして OpenHRP を用い, 人間型ロボットの作業移 動シミュレーションを行った。

シミュレーションに使用した人間型ロボットは, Fig. 7 に示 す HRP-1 モデル (全長約 $1.6[\mathrm{~m}]$, 全重量約 116 [kg]) [6] [29] である。このロボットは, 各腕 7 自由度, 各手の開閉 1 自由度, 各脚 6 自由度, 頭部 2 自由度の合計 30 自由度を持つ.ここで は簡単のため手の姿勢は考えないとし, 手首 3 自由度と腕のて 長 1 自由度を固定して腕を 3 自由度とした。また，手の開閉は 行わず，頭部自由度も固定した。このとき，ロボットの関節構 成は, Fig. 2 の手首 3 自由度を固定したものと同じになる.

Fig. 7 のように, 初期姿勢で両手は同じ高さにあり, 水平な 地面に両足接地している，地面に固定された世界座標系は，地 面上に原点を取り，両手を結ぶ直線に平行な方向を $Y$ 軸，それ と直角で水平な方向を $X$ 軸（前方が正）, 鉛直方向を $Z$ 軸（上 方が正）とする。初期姿勢に扔ける両手の位置と両足の位置. 姿勢を Table 1 にまとめる.

手の位置だけを考えるので，両手の理想インピーダンス $M_{h i}$, $D_{h i}, \quad K_{h i}(i=l, r)$ と作業移動評価関数 $U$ の重み行列 $K_{a}$ は $3 \times 3$ 行列となる。 また, 重み行列 $K_{z}$ は $2 \times 2$ 行列である.こ

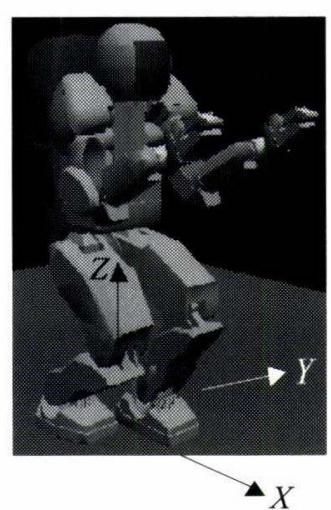

Fig. 7 Humanoid robot HRP-1 and global coordinate system in simulation 
Table 1 Initial pose of robot

\begin{tabular}{l|c}
\hline Left hand position & $(0.47,0.21,1.0)[\mathrm{m}]$ \\
\hline Right hand position & $(0.47,-0.21,1.0)[\mathrm{m}]$ \\
\hline Left foot position & $(0.15,0.10,0.0)[\mathrm{m}]$ \\
\hline Right foot position & $(-0.05,-0.10,0.0)[\mathrm{m}]$ \\
\hline Left foot orientation & parallel to $X$ axis \\
\hline Right foot orientation & parallel to $X$ axis \\
\hline
\end{tabular}

Table 2 Parameters of mobile manipulation control

\begin{tabular}{l|l}
\hline Hand impedance & $\begin{array}{l}m_{h}=1.0[\mathrm{~kg}], d_{h}=60.0[\mathrm{Ns} / \mathrm{m}], \\
k_{h}=1000.0[\mathrm{~N} / \mathrm{m}]\end{array}$ \\
\hline $\begin{array}{l}\text { Weight of } \\
\text { evaluation } U\end{array}$ & $\begin{array}{l}k_{a}=600.0, \\
k_{z x}=5000.0, k_{z y}=6000.0\end{array}$ \\
\hline Shoulder impedance & $\begin{array}{l}m_{s p}=0.9[\mathrm{~kg}], d_{s p}=1500.0[\mathrm{Ns} / \mathrm{m}], \\
m_{s z}=0.9\left[\mathrm{kgm}^{2}\right], d_{s z}=1500.0[\mathrm{Nsm}]\end{array}$ \\
\hline $\begin{array}{l}\text { Weight of } \\
\text { evaluation } V\end{array}$ & $V_{1}=10.0, V_{2}=10.0, V_{3}=100.0$ \\
\hline Stepping time & $t_{1}=1.0[\mathrm{~s}], t_{2}=1.0[\mathrm{~s}], t_{3}=1.5[\mathrm{~s}]$ \\
\hline Sampling time & $d t=0.001[\mathrm{~s}]$ \\
\hline $\begin{array}{l}\text { Minimum distance } \\
\text { between feet }\end{array}$ & $w_{y \min }=0.15[\mathrm{~m}]$ \\
\hline
\end{tabular}

れらは，次式の対角行列とする。

$$
\begin{aligned}
\left\{\begin{aligned}
M_{h l}= & M_{h r}=\operatorname{diag}\left(m_{h}, m_{h}, m_{h}\right) \\
D_{h l}= & D_{h r}=\operatorname{diag}\left(d_{h}, d_{h}, d_{h}\right) \\
K_{h l}= & K_{h r}=\operatorname{diag}\left(k_{h}, k_{h}, k_{h}\right)
\end{aligned}\right. \\
\left\{\begin{array}{l}
K_{a}=\operatorname{diag}\left(k_{a}, k_{a}, k_{a}\right) \\
K_{z}=\operatorname{diag}\left(k_{z x}, k_{z y}\right)
\end{array}\right.
\end{aligned}
$$

肩の運動は並進 3 方向と $Z$ 軸回りの回転を考え, 並進運動に関 する理想インピーダンスを $M_{s p}, D_{s p} \in R^{3 \times 3}, Z$ 軸回りの理 想インピーダンスを $m_{s z}, d_{s z}$ とする. $M_{s p}, D_{s p}$ は次の対角 行列とする。

$$
\left\{\begin{array}{l}
M_{s p}=\operatorname{diag}\left(m_{s p}, m_{s p}, m_{s p}\right) \\
D_{s p}=\operatorname{diag}\left(d_{s p}, d_{s p}, d_{s p}\right)
\end{array}\right.
$$

これら対角成分を含めた作業移動制御法の各パラメータは, Table 2 のように設定した。ここで， $w_{y \text { min }}$ は，ロボットの機構 によって決まる両足の横方向の最小接近可能距離である。ZMP の変動しやすい方向は両手の移動方向とし, 肩の予測位置·姿 勢や理想位置·姿勢は，4.3 節で述べたように決定する．各関節 の位置フィードバック・コントローラには, 関節角が目標值に 一致するようにフィードバックゲインを十分大きく設定したハ イゲイン・コントローラを用いた。

提案手法では, 式 (3) に両手の目標位置 $\boldsymbol{r}_{h i d}$. 目標速度 $\dot{\boldsymbol{r}}_{h i d}(i=l, r)$ を与えるだけで，それに応じた全身動作が自律的 に生成される。そこで, 様々な両手の目標軌道 $\boldsymbol{r}_{h i d}(t)$ を考え, シミュレーションを行った. 両手の目標外力は $\boldsymbol{f}_{\text {hid }}=0$ とした.

\section{2 両手の上下運動に伴う膝曲げ動作}

両手を上下に移動させる目標軌道 $\boldsymbol{r}_{h i d}(t)$ を与えたときのシ ミュレーションの結果を Fig. 8 に示す. 図から, 腕だけを動か して両手を下げるのではなく，両手の動きに合わせて膝を曲げ, 体全体を沈みこませていることが分かる。これは，両腕操作性 を高く保つ，すなわち肘を曲げた状態を保つためである.
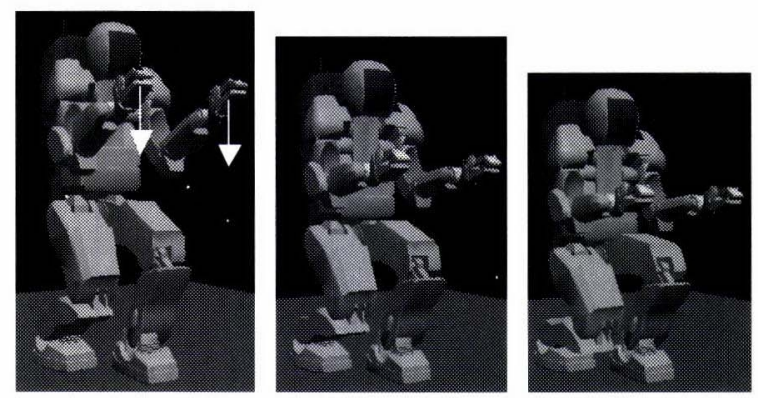

Fig. 8 Bending knees when both hands are going down
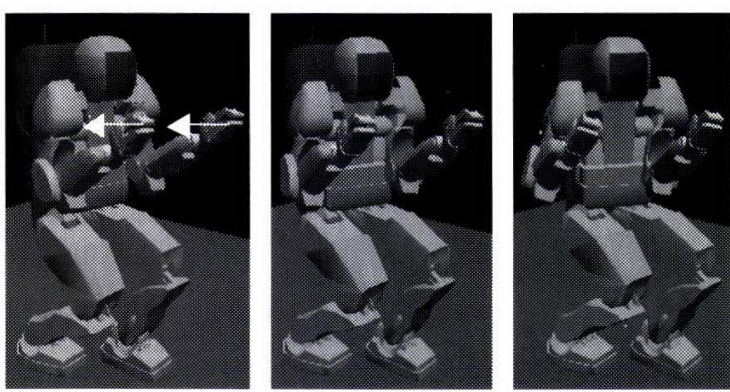

Fig. 9 Twisting body when both hands are moving back obliquely

\section{3 両手の斜め後方運動に伴う胴体捻り動作}

両手を斜め後方 $(-Y \&-X$ 方向）に移動させる目標軌道 $\boldsymbol{r}_{\text {hid }}(t)$ を与えたときのシミュレーションの結果を Fig. 9 に示 す.この場合も, 腕だけを動かすのではなく, 両腕操作性を高 く保つために体全体を捻り，両手を胴体の正面に持ってくる動 作が生成されている。

\section{4 両手の前方運動に伴う前進移動}

両手を初期位置から一定速度 $0.05[\mathrm{~m} / \mathrm{s}]$ で前方 $(+X$ 方向 $)$ に水平移動させる目標軌道 $\boldsymbol{r}_{h i d}(t)$ を与えた結果, Fig. $10(\mathrm{a})$ のように両手の運動にあわせた連続踏みかえが起こり, 前方へ 移動した。このときの手の $X$ 方向の軌道を Fig. 10 (b) に示す. 図から，作業移動の目的である「手を目標軌道に沿って動かす」 ことが実現できている.

\section{5 両手の横運動に伴う横移動}

両手を初期位置から一定速度 $0.02[\mathrm{~m} / \mathrm{s}]$ で真横 $(-Y$ 方向 $)$ に水平移動させる目標軌道 $\boldsymbol{r}_{h i d}(t)$ を与えたときのシミュレー ションの結果をFig. 11 (a)に示す．まず，両腕操作性を高く保 つために両手を胴体正面に持ってくる必要から，胴体は向きを 変えずに横移動する。その結果, 左足を内側に寄せ, 右足を外側 に開き, 再び左足を寄せることを繰り返す両脚の横移動（連続 踏みかえ）が生成された。この動作は，例えば人間同士が机の 左右両端を持って前後に移動させるときの動きに似ている。こ のときの両着地点の変化を Fig. 11 (b) に示す. 図から, 着地点 は横方向 $(Y$ 方向) に変化しているだけでなく, 前後方向 $(X$ 方向）にも変化していることが分かる。これは, 着地点を決定 する際に, 安定領域の方向を考虑しているためである。この運 動では, ZMP は横方向に变動しやすい. よって, 安定領域の長 手方向が横向きになるように, すなわち両足が真横にそろうよ うに着地点が生成されている. 最初の左足の横方向移動量が少 
幸太郎 新 井健 生前泰志

ないのは, 両足の横方向の最小接近可能距離が $0.15[\mathrm{~m}]$ に制限 されているためである.作業移動評価関数 $U$ を構成する両腕操 作性の評価值 $U_{a}$ とロボット安定性の評価值 $U_{z}$ が相反する関係 にある場合は, 設定した重み行列 $K_{a}, K_{z}$ によって一方の評価 值が優先される.このシミュレーションでは， $U_{z}$ の重みを大き くとることで，踏みかえ時（Fig. 11 (a) の $5.0[\mathrm{~s}]$ や $8.5[\mathrm{~s}]$ ) の 体重移動を実現している。 その反面, 踏みかえ中は両腕が少し 伸び, 両腕操作性は下がっている.

\section{6 パネル立て掛け作業}

作業移動制御法では，手に外力が作用する状況でも，ロボッ 卜安定性を維持するように全身動作を生成する。 HRP プロジェ クトの屋外共同作業におけるパネル運搬・組み付けはこのよう な作業の一例であり，作業移動制御法を適用できる，

そこで, パネル立て掛け作業のシミュレーションを行った。 パネ ルのサイズは $1.6[\mathrm{~m}] \times 0.8[\mathrm{~m}] \times 0.06[\mathrm{~m}]$ で, 重量は $4.0[\mathrm{~kg}]$ で ある。パネルの下端を床と壁で支え，パネル上部を手で押すよう に両手に目標水平軌道 $\boldsymbol{r}_{\text {hid }}(t)$ (高さ $0.93[\mathrm{~m}]$, 速度 $0.05[\mathrm{~m} / \mathrm{s}]$ ) を与えた.シミュレーション結果をFig. 12 に示す. 図のよう

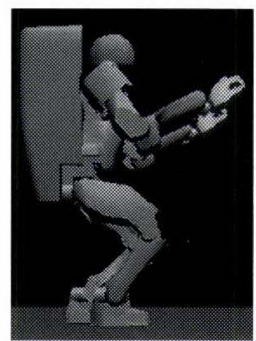

$4.0[\mathrm{~s}]$

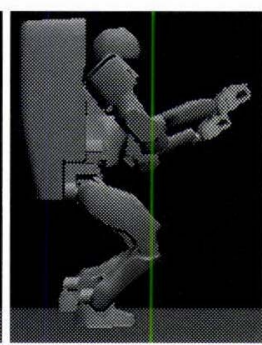

$6.0[\mathrm{~s}]$

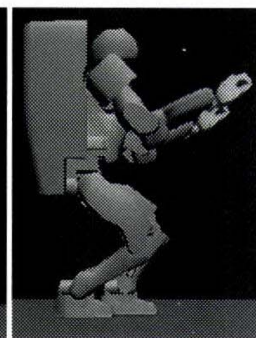

$8.0[\mathrm{~s}]$ (a) Motion of robot

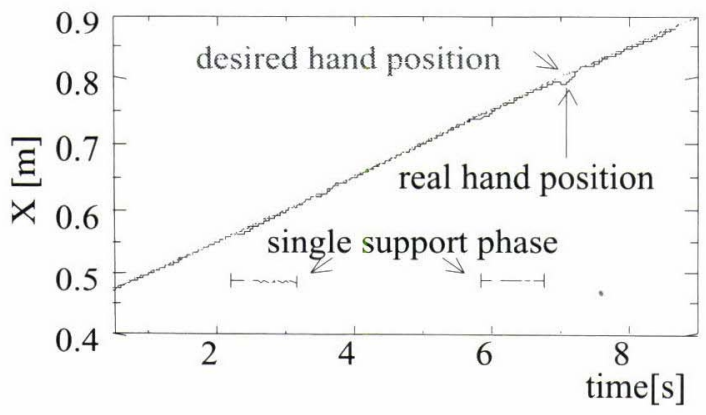

(b) Hand trajectory in $X$-direction

Fig. 10 Forward stepping when both hands are moving forward
に, 作業移動制御法により自律的に 2 歩踏みかえ, 約 $7.5[\mathrm{~s}]$ で パネル立て掛けに成功した。

\section{7 考察}

以上のシミュレーション結果から，開発した制御手法により， 両手の運動に応じた平面上での人間型ロボットの作業移動が実 現できることが確認できた。踏みかえを伴うシミュレーション では，遊脚の移動にかかる時間が $1[\mathrm{~s}]$ 強であった。これは，作 業移動が高速歩行を目指したものではなく，「手作業を遂行する

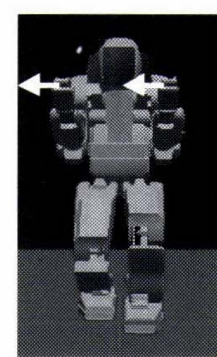

$1.0[\mathrm{~s}]$

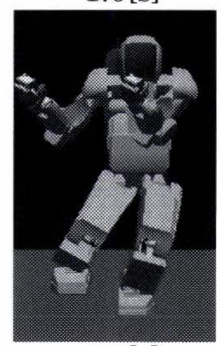

$5.0[\mathrm{~s}]$

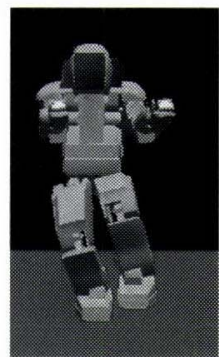

$1.5[\mathrm{~s}]$

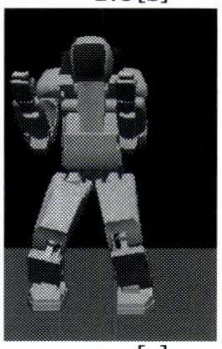

$7.0[\mathrm{~s}]$

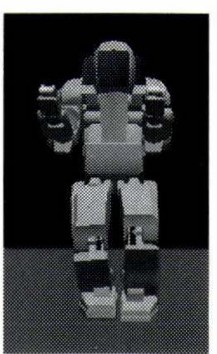

$3.0[\mathrm{~s}]$

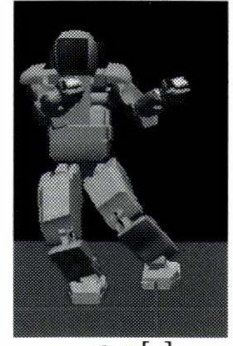

$8.5[\mathrm{~s}]$ (a) Motion of robot

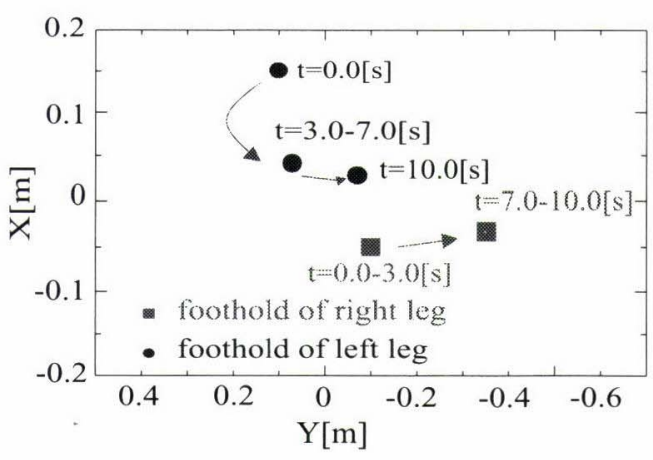

(b) Footholds in side stepping

Fig. 11 Side stepping when both hands are moving sideward
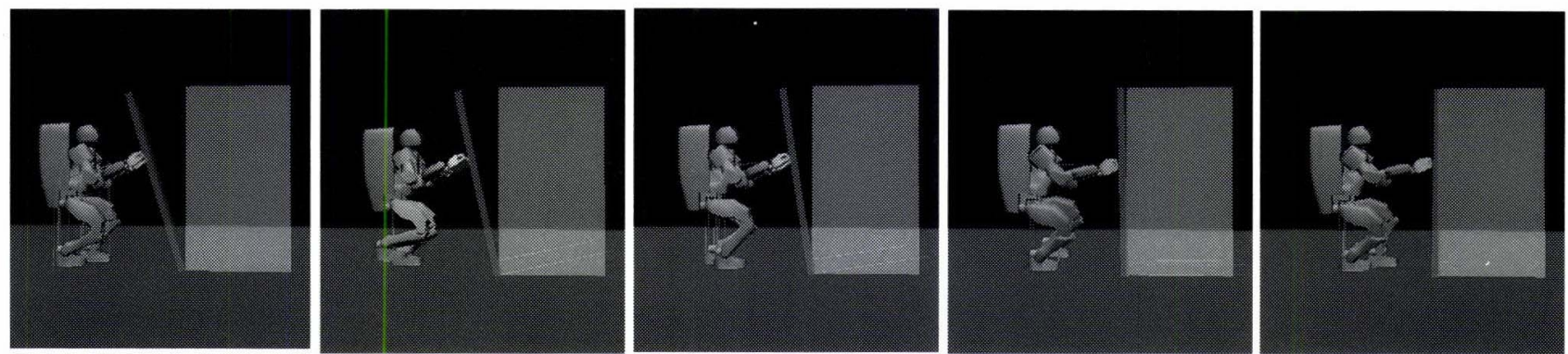

Fig. 12 Leaning panel against wall 
のに最もよい両脚支持状態へ，一歩ずつ安定に踏みかえる」と いう考え方に立っているためである。

手による目的作業の遂行と踏みかえに必要な体重移動を同時 に実現しようとすると, 手の移動方向と肩の移動方向が必ずし も一致しないため, 踏みかえ中に腕が可動限界に近くなること がある. Fig. 11 の横移動は，両者が反対向きになる顕著な場合 といえる，一方，Fig. 10 の前進移動では，腕の姿勢はあまり変 わらない。この現象は，人間型ロボットが踏みかえのために体 重移動しなければならない以上, 避けられない. 腕が可動限界 に達した場合は，手作業を一時中断して踏みかえ，作業を再開 するといった戦略をとる必要がある。これは，作業と移動を切 り離して行うことになるので, 本研究では扱っていない.

パネル立て掛け作業のシミュレーションでは，ロボットの自 重に比べてパネルが軽いため立て掛けに成功した。しかし，本 研究で提案した作業移動制御法は、ロボットが自重を使って押 さなければならないほどの重量物を扱う状況は想定していない. 我々は，作業移動制御法をベースとしてより大きな外力が手に 作用する場合にも対処できる手法を提案し, 現在, 人間サイズ の人間型ロボット HRP-2 [5] に実装して重量物押し作業実験を 行っている.

\section{6.おわりに}

本研究では，手作業を目的とした人間型ロボットの作業移動 制御法を提案した。この方法では，両手で目的作業を遂行しな がら，その動きに応じて両腕操作性・ロボット安定性を高める ように胴体・脚を制御する.胴体・脚制御は両脚支持状態での 胴体姿勢制御と踏みかえ動作からなり，それらを自律的に切り 替えることで, 器用かつ安定な手作業を可能にする. 両手が大 きく運動すると連続踏みかえが起こり，手作業を主体とする移 動が実現される．OpenHRPを用いて人間型ロボットHRP-1 の動作シミュレーションを行い, 提案手法により作業移動が実 現できることを確認した。 また，HRP-1によるパネル立て掛け 作業のシミュレーションも行い, 提案手法が実作業に応用可能 であることを示した，作業移動は単なる歩行とは異なり，「手作 業を行う」という視点に立った人間型ロボットの新しい応用の 可能性を示唆するものといえよう.

本論文で提案した方法は作業移動の一形態であり, 歩行しな がらの作業や趾いた姿勢での作業など，人間型ロボットが作業 を行う方法はいろいろ考えられる．様々な作業方法を実現する アルゴリズムを開発し，それらを人間型ロボット HRP-2に実 装して実験, 検証することが今後の課題である.

謝 辞 本研究は, 経済産業省産業科学技術研究開発制度「人 間協調・共存型ロボットシステム研究開発」(平成 $12 \sim 14$ 年度) の一環として行われた.

\section{参 考 文 献}

[1] 平井, 仲山：“ロボットプラットフォームの製作㧍よび高機能ハンド の開発”, 日本ロボット学会誌, vol.19, no.1, pp.8-15, 2001.

[2] T. Ishida, Y. Kuroki and J. Yamaguchi: "Mechanical System of a Small Biped Entertainment Robot," Proc. IROS2003, pp.1129-1134, 2003.

[ 3 ] Y. Ogura, et al.: "Development of a Human-like Walking Robot
Having Two 7-DOF Legs and a 2-DOF Waist," Proc. IEEE ICRA2004, pp.134-139, 2004.

[4] J. Kim and J. Oh: "Walking Control of the Humanoid Platform KHR-1 based on Torque Feedback Control," Proc. IEEE ICRA2004, pp.623-628, 2004.

[5] K. Kaneko, et al.: "Humanoid Robot HRP-2," Proc. IEEE ICRA2004, pp.1083-1090, 2004.

[6] 金広他：“ヒューマノイドロボット（HRP-1S）の全身運動制御シス テム”, 日本ロボット学会誌, vol.22, no.1, pp.20-27, 2004.

[7] S. Kajita, et al.: "Resolved Momentum Control: Humanoid Motion Planning based on the Linear and Angular Momentum," Proc. IROS2003, pp.1644-1650, 2003.

[8] K. Nagasaka, et al.: "Integrated Motion Control for Walking, Jumping and Running on a Small Bipedal Entertainment Robot," Proc. IEEE ICRA2004, pp.3189-3194, 2004.

[9] K. Okada, M. Inaba and H. Inoue: "Walking Navigation System of Humanoid Robot using Stereo Vision based Floor Recognition and Path Planning with Multi-Layered Body Image," Proc. IROS2003, pp.2155-2160, 2003.

[10] K. Sabe, et al.: "Obstacle Avoidance and Path Planning for Humanoid Robots using Stereo Vision," Proc. IEEE ICRA2004, pp.592-597, 2004.

[11] F. Kanehiro, et al.: "Locomotion Planning of Humanoid Robots to Pass through Narrow Spaces," Proc. IEEE ICRA2004, pp.604-609, 2004.

[12] M. Fujita, et al.: "Autonomous Behavior Control Architecture of Entertainment Humanoid Robot SDR-4X," Proc. IROS2003, pp.960-967, 2003.

[13] Y. Kuroki, et al.: "Motion Creating System for a Small Biped Entertainment Robot," Proc. IROS2003, pp.1394-1399, 2003.

[14] S. Kagami, et al.: "Humanoid Arm Motion Planning using Stereo Vision and RRT Search," Proc. IROS2003, pp.2167$2172,2003$.

[15] K. Terada, Y. Ohmura and Y. Kuniyoshi: "Analysis and Control of Whole Body Dynamic Humanoid Motion -Towards Experiments on a Roll-and-Rise Motion," Proc. IROS2003, pp.1382-1387, 2003.

[16] K. Fujiwara, et al.: "Falling Motion Control of a Humanoid Robot Traind by Virtual Supplementary Tests," Proc. IEEE ICRA2004, pp.1077-1082, 2004

[17] 金広他：“ヒューマノイドの転倒回復機能の実現”, 日本ロボット学 会誌, vol.22, no.1, pp.37-45, 2004.

[18] 舘 他：“HRP 遠隔操作プラットフォーム”、日本ロボット学会誌, vol.19, no.1, pp.16-27, 2001.

[19] K. Yokoi, et al.: "A Tele-operated Humanoid Robot Drives a Backhoe in the Open Air," Proc. IROS2003, pp.1117-1122, 2003.

[20] N.E. Sian, et al.: "Whole Body Teleoperation of a Humanoid Robot Integrating Operator's Intention and Robot's Autonomy -An Experimental Verification," Proc. IROS2003, pp.16511656, 2003.

[21] 比留川他： “HRP 仮想プラットフォームにおける幾可計算サーバ”, 日本機械学会ロボティクス・メカトロクス講演会'99 講演論文集, $2 \mathrm{p} 2-$ 78-094, 1999.

[22] Y. Nakamura, et al.: "Dynamics Computation of StructureVaryng Kinematic Chains and Its Application to Human Figures," IEEE Trans. on Robotics and Automation, vol.16, no.2, pp.124-134, 2000.

[23] 中村 他：“仮想ロボットプラットフォーム”, 日本ロボット学会誌, vol.19, no.1, pp.28-36, 2001.

[24] K. Okada, et al.: "Integrated System Software for HRP2 Humanoid," Proc. IEEE ICRA2004, pp.3207-3212, 2004.

[25] 井上：“人間型ロボットが拓く未来社会と新産業の創成”, 日本ロボッ 卜学会誌, vol.22, no.1, pp.2-5, 2004.

[26] 比留川: “人間型ロボットの近未来応用”, 日本ロボット学会誌, vol.22, no.1, pp.6-9, 2004.

[27] K. Sakata, K. Inoue, T. Takubo, T. Arai and Y. Mae: "Pro- 
posal of Wheelchair Support System Using Humanoid Robots for Creating SSR Society," Proc. SSR2003, pp.53-58, 2003.

[28] 井上, 比留川：“人間協調・共存型ロボットシステム研究開発プロジェ クト”, 日本ロボット学会誌, vol.19, no.1, pp.2-7, 2001.

[29] 新エネルギー・産業技術総合開発機構：人間協調・共存型ロボットシ ステム研究開発成果報告書, 2003.

[30] Y. Hwang, A. Konno and M. Uchiyama: "Whole Body Cooperative Tasks and Static Stability Evaluations for a Humanoid Robot," Proc. IROS2003, pp.1901-1906, 2003.

[31] 原田 他： “ヒューマノイドロボットの脚腕協調に求ける ZMP 解析”, 日本ロボット学会誌, vol.22, no.1, pp.28-36, 2004.

[32] K. Harada, et al.: "Real-time Planning of Humanoid Robot's Gait for Force Controlled Manipulation," Proc. IEEE ICRA2004, pp.616-622, 2004.

[33] 井上, 石井, 大川：“手先で作業をしながら移動する腕付 2 足歩行ロボッ トの制御”, 第 16 回日本ロボット学会学術講演会予稿集, pp.10951096,1998 .
[34] 井上, 石井, 大川：“腕で作業をしながら移動する人間型ロボットの 実時間制御 (Sagittal Plane 内の運動の制御)”, 日本ロボット学会 誌, vol.18, no.1, pp.75-86, 2000.

[35] 井上, 吉田, 新井, 前: “手先の遠隔操作によるヒューマノイドの作業 移動”, 第 5 回ロボティクスシンポジア予稿集, pp.333-338, 2000.

[36] K. Inoue, H. Yoshida, T. Arai and Y. Mae: "Mobile Manipulation of Humanoids: Real-Time Control Based on Manipulability and Stability," Proc. IEEE ICRA2000, pp.2217-2222, 2000.

[37] H. Yoshida, K. Inoue, T. Arai and Y. Mae: "Mobile Manipulation of Humanoid Robots: Analysis of Manipulability and Stability in Mobile Manipulation," Proc. IROS2000, pp.19241929, 2000.

[38] 吉田, 井上, 新井, 前: “人間型ロボットの作業移動（作業移動に要求され る脚機能の分析) ”, 日本ロボット学会誌, vol.19, no.5, pp.660-666, 2001.

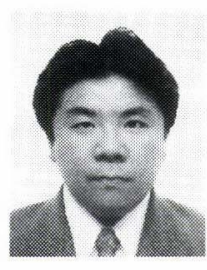

\section{井上健司（Kenji Inoue）}

1963 年 10 月 10 日生. 1988 年東京大学大学院工学 系研究科修士課程修了. 同年東京大学工学部助手. 大阪大学工学部助手, 同学部講師, 大阪大学大学院 基礎工学研究科講師を経て, 2001 年同研究科助教 授となり現在に至る。人間型ロボット，ハプティッ ク・デバイス，レスキューロボット，作業移動型ロ ボットなどの研究に従事. 博士 (工学)。日本機械学会, 計測自動制 御学会, 日本バーチャルリアリティ学会, 精密工学会の会員.

(日本ロボット学会正会員)

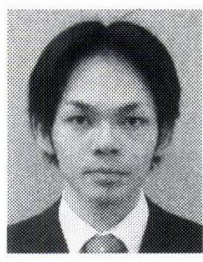

\section{坂田幸太郎（Kotaro Sakata）}

1980 年 1 月 5 日生. 2003 年大阪大学基礎工 学部システム科学科卒業. 2005 年同大学大学院 基礎工学研究科システム創成専攻博士前期課程 修了. 同年, 松下電器産業株式会社入社. 現在, 同社本社 $R \& D$ 部門 $A V$ コア技術開発センター に所属. 在学中, 人間型ロボットの研究に従事.

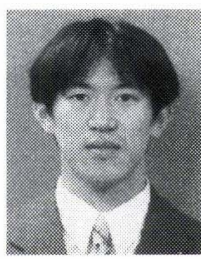

\section{前 泰志 (Yasushi Mae)}

1971 年 3 月 11 日生. 1993 年大阪大学工学部電子 制御機械工学科卒業, 1998 年同大学大学院工学研 究科電子制御機械工学専攻博士課程修了, 博士（工 学). 同年, 同大学大学院基礎工学研究科助手. 2004 年福井大学工学部助教授、ロボットビジョン, 作業 移動型ロボット，環境の知能化などの研究に従事. 情報処理学会, 日本バーチャルリアリティ学会の会員.

(日本ロボット学会正会員)

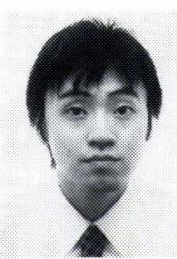

西濱祐介（Yusuke Nishihama）

1977 年 10 月 22 日生. 2001 年大阪大学基礎工学 部システム科学科卒業. 2003 年同大学大学院基礎 工学研究科システム創成専攻博士前期課程修了. 同 年, 日本電気株式会社入社. 現在, 同社 $\mathrm{MC}$ ビジネ スユニットNWソフトウェア事業本部に所属. 在 学中, 人間型ロボットの研究に従事.

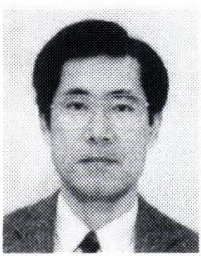

新井健生（Tatsuo Arai）

1952 年 1 月 6 日生. 1977 年東京大学大学院工学 系修士課程修了。工業技術院機械技術研究所を経 て, 現在大阪大学大学院基礎工学研究科教授. パラ レルメカニズム, マイクロマニピュレーション, 作 業移動型ロボット等の研究に従事. 1986 1987 年 MIT 客員研究員. 日本機械学会, 計測自動制御学 会, IEEE 等の会員. 